\title{
Huff and puff, you "Big Bad Wolf": Our brick house won't fall!
}

\author{
W. Randolph Chitwood, Jr, MD, FACS, FRCS
}

\author{
From the East Carolina Heart Institute; the Department of Surgery, Brody School of Medicine, East Carolina Uni- \\ versity; and the Vidant Medical Center, Greenville, NC \\ Disclosures: Author has nothing to disclose with regard to commercial support. \\ Received for publication March 10, 2017; accepted for publication March 17, 2017. \\ Address for reprints: W. Randolph Chitwood, Jr, MD, FACS, FRCS, 146 E Longmeadow Rd, Greenville, NC \\ 27858 (E-mail: chitwoodw@ecu.edu). \\ J Thorac Cardiovasc Surg 2017;153:1290 \\ $0022-5223 / \$ 36.00$ \\ Copyright (C) 2017 Published by Elsevier Inc. on behalf of The American Association for Thoracic Surgery \\ http://dx.doi.org/10.1016/j.jtcvs.2017.03.060
}

Which of the Three Little Pigs are we as cardiac surgeons? Surgeons have always led the way in developing new technology to treat valvular heart disease. Before 1977, when Gruntzig performed the first coronary angioplasty, adult cardiac surgeons never considered that cardiac catheters could ever be used for anything but diagnostics. Yes, Rashkind did bring us atrial septal balloon septostomies in 1966, but then there had never been a thought to treat coronary or valvular disease with catheters. Yikes! The hue and cry in the 1980s was that balloon angioplasty would eclipse coronary surgery forever. It never did, and we were busier than ever as more coronary disease was discovered. That "Big Bad Wolf" really became a minimal threat. Then came the stents: "They will never work" or "What if they do work?" Then came atherectomy catheters and rotablatorsand during this era, we were still busy doing coronary surgery. Thank God for the internal thoracic artery, which proved to be a better option than a vein graft or a stent. Bully for the recent SYNTAX trial, which proved that coronary surgery was still in the game and often much better that catheter interventions. The positive outcomes from advanced coronary stents, statin drug therapy, flow-wire diagnostics, and even lifestyle modification have made major therapeutic impacts on survival and complications. These Big Bad Wolves did not eliminate coronary surgery, albeit somewhat less than in the past. Today, coronary therapy has become multifaceted, with each form having a major advantage. Innovation always becomes an iterative process! From vacuum tubes to transistors, integrated circuits, megachips, Internet—all in less than 50 years. In just 15 years, transcatheter aortic valve replacement (TAVR) has evolved along the same iterative pathway to become a highly acceptable therapy for aortic stenosis.

So, remember this evolutionary process when thinking about the Big Bad Wolf that Mumtaz and associates ${ }^{1}$ are talking about with regard to TAVR in their article in this issue of the Journal. Take a lesson from the fairytale about the anthropomorphic Three Little Pigs and the Big Bad Wolf. Only by building our clinical "brick house" can we Little Pigs remain as the major players in treating valvular

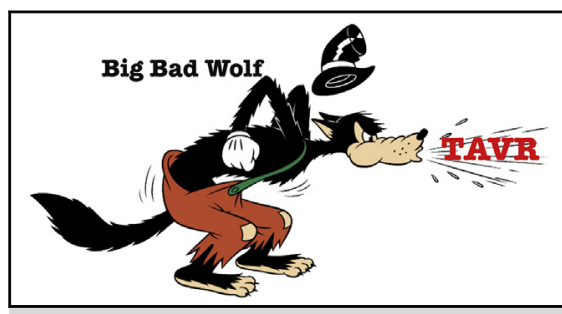

TAVR is not a Big Bad Wolf-unless we Little Pigs (surgeons) build weak houses!

Central Message

There is no "Big Bad Wolf." We must embrace transcatheter aortic valve replacement. These devices already have proven efficacy in intermediate risk settings relative to surgical replacements.

See Article page 1287.

heart disease. We must embrace that Big Bad Wolf and adopt TAVR, as well as other evolving technologies, into our valvular heart disease therapeutic armamentarium.

The dirty little secret is that TAVR valves work well, and companies have solved most of their problems iteratively. First, it was the problem of the femoral access, then gradients, then strokes, then paravalvular leaks, then operator ease. The question of durability exists for all biologic valves, whether surgical or catheter based. In this, respect pyrolytic carbon may trump tissue preparations for a long time. Of course, the evolving tissue "secret sauce" treatments may extend the life of both tissue valve devices. As Mumtaz and associates ${ }^{1}$ state, even at 5 years there has been little structural degeneration in TAVR valves.

As Mumtaz and associates ${ }^{1}$ note, the future of TAVR may already have been predicted by positive results of intermediate-risk clinical trials. Now we will get a chance to follow patients up for 10 years in the upcoming studies in low-risk patients. Previously, higher-risk patients were treated, but the valve usually outlasted the patient. Now cardiologists and surgeons can learn together which tissue valve-surgical or transcatheter-will last longer. The door is still wide open, and we "Little Pigs" must continue to build strong houses by embracing this technology. Mumtaz and associates ${ }^{1}$ are right! Then-there will be no "Big Bad Wolf" for any of us!

\section{Reference}

1. Mumtaz M, Gada H, Mack MJ, Reardon MJ. Who's afraid of the big bad wolf? J Thorac Cardiovasc Surg. 2017;153:1287-9. 